\title{
递/ QUEEN'S UNIVERSITY BELFAST

\section{Youth in (times of) Crisis: Migration, precarity, and shifting identities in the Southern borders of Europe}

Chatzipanagiotidou, E. (2018). Youth in (times of) Crisis: Migration, precarity, and shifting identities in the Southern borders of Europe. Transnational Social Review, 8(3), 231.

https://doi.org/10.1080/21931674.2018.1510883

\section{Published in:}

Transnational Social Review

\section{Document Version:}

Peer reviewed version

Queen's University Belfast - Research Portal:

Link to publication record in Queen's University Belfast Research Portal

\section{Publisher rights}

(C) 2018 Informa UK Limited, trading as Taylor \& Francis Group. This work is made available online in accordance with the publisher's policies. Please refer to any applicable terms of use of the publisher.

\section{General rights}

Copyright for the publications made accessible via the Queen's University Belfast Research Portal is retained by the author(s) and / or other copyright owners and it is a condition of accessing these publications that users recognise and abide by the legal requirements associated with these rights.

Take down policy

The Research Portal is Queen's institutional repository that provides access to Queen's research output. Every effort has been made to ensure that content in the Research Portal does not infringe any person's rights, or applicable UK laws. If you discover content in the Research Portal that you believe breaches copyright or violates any law, please contact openaccess@qub.ac.uk. 
acknowledgement: 'The Version of Record of this manuscript has been published and is available in Transnational Social Review 8:03 http://www.tandfonline.com/ DOI: 10.1080/21931674.2018.1510883

Youth in (times of) Crisis: Migration, precarity, and shifting identities in the Southern borders of Europe

Evropi Chatzipanagiotidou

School of History, Anthropology, Philosophy and Politics, Queen's University Belfast, UK

Address: School of History, Anthropology, Philosophy and Politics, 14 University Square, Queen's University Belfast, BT7 1NN, UK. Email: e.chatzipanagiotidou@qub.ac.uk Tel.: +44 (0)2890973704 


\section{Youth in (times of) Crisis: Migration, precarity, and shifting identities in the Southern borders of Europe}

This article traces youth migration from Greece to Cyprus in the context of the ongoing economic crisis, and reveals the impact of labor conditions, precarity and mobility on the lives and aspirations of young migrants. I interrogate jointly the categories of "youth" and "migrant", and argue that, far from being fixed, these are produced and redefined by the temporalizing and historicizing effects of the crisis, the former as a protracted state of being, and the latter as a phenomenon of contingency that needs to be addressed through policies of economic recovery and development. At the same time, the article documents the dynamic ways, in which young migrants engage in, reproduce and resist discourses and structures that shape their everyday life and hopes for the future. The intra-Southern European migration from Greece to Cyprus, offers a distinctive ethnographic context to document how new migratory routes develop, especially in a terrain of intersecting economic crises in the southern borders of Europe. Migration in this case is not, as often assumed, a linear, one-way direction, but an ongoing process of decision-making around new opportunities, destinations and mobilities.

Keywords: youth; crisis; migration; precarity; Greece; Cyprus. 


\section{Introduction}

In his first speech after his election as a Prime Minister in January 2015, Syriza leader, Alexis Tsipras, dedicated his victory to young Greeks living abroad and emphasized his Party's commitment to bringing these migrants back by rebuilding the country. The Prime Minister's speech echoed concerns about youth emigration from Greece as a result of the economic crisis, ${ }^{\mathrm{i}}$ which are pervasive in political and policy rhetoric, media discourse and popular and everyday narratives. Outside Greece, international newspapers, such as the Guardian, have raised similar worries with articles such as: "Who'd be young and Greek" (Howden \& Baboulias, 2015) and "Young, Gifted and Greek" (Smith, 2015), describing the emigrants as "Generation G," and a worrying example of brain-drain.

These accounts present youth emigration as a phenomenon of social, economic and political rupture in a temporal terrain that demarcates a well-defined shift from the past. Therefore, young migrants' outward mobility emerges not only as a metonymical category of the Greek economic crisis, but also as crisis per se. Crucially, what also underlie such perspectives are moral and moralizing debates that present a double bind: on the one hand, youth unemployment is perceived as an obstacle to both the socio-economic progress of young people in the capitalist market and their life trajectory to adulthood, processes that are imagined as linear and attached to specific considerations and aspirations. On the other hand, migration is pathologized as a "necessary evil" that should be addressed through policies of development and practices of return. The "choice" not to migrate by some young people is celebrated in public discourses and narratives as an honorable and sacrificial act. To emigrate, on the contrary, often triggers affective dynamics of blame towards migrants for "giving up," and guilt for leaving the country when it is most in need. 
Beyond a strong focus on the exodus of young people, however, there is very little analysis in these standardized discourses of the experiences of those who have emigrated. This research traces youth migration from Greece ${ }^{\mathrm{ii}}$ to Cyprus, and reveals the impact of labor conditions, precarity and mobility on the lives and aspirations of young migrants. Through this lens, I interrogate jointly the categories of "youth" and "migrant", and argue that, far from being fixed, they are produced and redefined both as discourses and lived experiences through the operations of the crisis as mechanisms of governmentality (Athanasiou, 2012) and embodied interactions. This is not to say that migrants are passive respondents to broader sociopolitical and economic processes. Quite the reverse; the article documents the dynamic ways, in which they engage in, reproduce and resist discourses and structures that shape their everyday life and hopes for the future.

Although most migrant movement is northward, to countries of Northern Europe, the US, Canada, and Australia, I choose to focus here on a southward route. The former are popular destinations due to economic opportunities and other pull factors, and places where migrants may already have social and family networks - some of them established through previous waves of Greek emigration in the post-WWII decades (Fakiolas \& King, 1992). While those destinations tend to attract more public attention, the intra-Southern European migration from Greece to Cyprus, offers a unique ethnographic context to document how new migratory routes develop, especially in a terrain of intersecting economic crises in the southern borders of Europe. Migration in this case is not, as often assumed, a linear, one-way direction, but an ongoing process of decision making around new opportunities, destinations and mobilities. Furthermore, although significant attention has been on a European North-South divide in the context of the economic crisis and around cultural and nationalist frameworks (see Herzfeld, 2013), I argue that the visibility of Greek migrants in Cyprus has exposed historical motifs and 
political dynamics in the area. Far from homogenous, the European South is also a field of socio-cultural and ideological contestations over identity, belonging and domination.

The paper is informed by long-term research in Cyprus since 2007, although the main material used here was collected through ethnographic fieldwork in 2013 and 2016 in the Republic of Cyprus, over four and three months respectively ${ }^{\mathrm{iii}}$. The main bulk of the research was conducted first at a time when Greek migration to Cyprus had peaked and, simultaneously, Cyprus officially entered a period of austerity through an Economic Adjustment Program. I complemented this with comparative research in 2016 in order to trace the effects of the Cypriot economic crisis on patterns and experiences of migration. The material was collected through participant observation in workplaces and social spaces across the Republic of Cyprus, online research in social media and forums, as well as 28 in-depth interviews with Greek migrants, ${ }^{\text {iv }}$ most of them in their twenties and thirties. ${ }^{\mathrm{v}}$ The migrants come from all parts of Greece and are of diverse backgrounds and different socio-economic and employment status. Although a considerable number are highly-skilled professionals, who work in the public and private sector, and in fields such as education, medicine, law, finance and trade, large numbers of migrants, including some with university degrees, are employed as un-skilled or semi-skilled labor in the hospitality and services industry, trade and office jobs. As the main focus of the research is on precarity, most interviews were conducted with the latter group. In addition to economic reasons, Cyprus, due to a perceived cultural closeness and shared language, also attracts a particular demographic of Greek migrants, who often lack the social and cultural capital to move to other parts of Europe.

I start below by bringing together anthropological approaches to youth (see Bucholtz, 2002; Durham, 2004; Mains, 2007; Jeffrey, 2010; Rohrer, 2014) with critical perspectives on the Greek crisis (Athanasiou, 2012; Dalakoglou, 2012; Knight, 2012; Davis, 2015; Dalakoglou \& Agelopoulos, 2018) to argue that through temporalizing and historicizing tropes, youth is 
redefined as a protracted state of being, and migration as a phenomenon of contingency that needs to be addressed through policies of economic recovery and development. The following section diverts attention to migrants, and documents the ways in which they experience the crisis and precarity through a temporal framework of waiting and progress, both personal and professional. Migration is framed as the main strategy of overcoming time-wasting, but it does not always fulfil expectations, especially in a context where migrants experience a second economic crisis in their host country. The final section examines how such intersecting crises and historical socio-cultural narratives provide a platform, through which the category of the (non-)migrant is debated and contested.

\section{Youth and Migration in Crisis: anthropological perspectives}

Youth has been studied by psychologists as a specific age category (with most studies focusing on adolescence) and a period of uncertainty, liminality and transition (see for instance Erikson, 1994). Such transformations are normally linked to physiological and biological transformations, traced through the development of the body (Rohrer, 2014, p. 38) and of cognitive and affective qualities. These analyses, that regularly dominate public and policy understandings, biologize and naturalize youth (Bucholtz, 2002, p. 531), and treat it as an inescapable and universal stage of human life, after which individuals achieve full adulthood.

On the other hand, anthropological work has challenged such prevailing accounts and periodizations through cross-cultural and historical comparisons that move beyond Westerncentric paradigms of age, adolescence and adulthood. Bucholtz (ibid., p. 526) alerts to the difficulty in defining youth, which "in some situations may be based on one's social circumstances rather than chronological age or cultural positions.” By tracing socio-political and economic changes in Botswana in the 1980s and 1990s, Durham (2004) shows how the meaning of youth, and who is included in the category, can shift. Youth is not only relational but also a political and pragmatic act, a "social shifter" (ibid., p. 592). 
"To call someone a youth is to position him or her in terms of a variety of social attributes, including not only age, but also independence-dependence, authority, rights, abilities, knowledge, responsibilities, and so on. But in the pragmatic and political processes in which such namings take place, the category itself is reconstructed and the attributes repositioned among those involved" (ibid., p. 593).

Definitions and experiences of youth, therefore, are not independent of both specific cultural contexts and broader structural conditions, as anthropologists have argued by exploring the effects of globalization, neoliberalism and migration on the lives of young people and (re)articulations of “youth” (see Bucholtz, 1999; Katz, 2004; Mains, 2007; Jeffrey, 2010). In Greece, unemployed youth are framed as a "lost generation", who cannot achieve the social mobility and full adulthood that education and employment were supposed to secure. Such arguments "are often politically motivated and address shifting social configurations, political reorganization, cultural politics, and new philosophical movements about the nature of human beings and society" (Durham, 2004, p. 591).

Anthropological work on the economic crisis in Europe and Greece challenges dominant accounts of "the crisis" as a moment of rupture that demands emergency methods and austerity measures. Athanasiou analyzes the crisis as a mechanism of neoliberal governmentality that makes alternative visions of society and economy redundant:

"Predicated upon this doctrine, discourses of crisis become a way to governmentally produce and manage (rather than deter) the crisis. "Crisis" becomes a perennial state of exception that $[\ldots]$ renders critical thinking and acting redundant, irrational, and ultimately unpatriotic" (cited in Boletsi, 2017 p. 261). 
Within this logic, there emerges a paradox of treating phenomena, like emigration, as both a cause and an effect of the crisis, in the sense that the exodus of young people further entrenches economic stagnation through brain-drain and loss of productive labor.

Quite similarly to the issue of suicide in Greece as analyzed by Davis (2015), the crisis also elevates migration from the individual/personal to the collective/social, and makes it historical and historically contingent (ibid., p. 1030). This historicizing of migration operates through an emphasis of discontinuities and ruptures from the past, through descriptions of an "unprecedented phenomenon" and a "mass exodus," which Greece had not experienced for some time. In colloquial analyses of the crisis, a common saying in Greece is that "this is the first generation after WWII who will live worse than their parents," and reproduces the misleading assumption of a past linear economic progress and social mobility-which, although available to some, was not experienced by everyone. The language of crisis therefore homogenizes the past and disguises continuities of inequality and stratification, by representing contemporary youth in Greece as operating in conditions that divert from an expected trajectory. At the same time, the current emigration waves are paralleled and compared to previous periods of emigration in Greek history in order to draw similarities and differences; a trope that Knight (2012) calls "polytemporality." According to Knight, "polytemporality” often exhibits strong inter-generational elements, by which contemporary hardships and difficulties faced by younger people are downplayed as less grave than those experienced by previous generations - a narrative also reproduced and internalized by youth. As one of my research participants commented after realizing that his flight to Cyprus was full of other migrants: "It's like our grandfathers when they were boarding trains to go to Germany [as migrants]. It used to take days to get there. Life was much harder then. At least it's not that bad for us."

The historicizing effect of crisis, however, has to be confronted politically, analytically and methodologically. The trope of "rupture" does not only allow for particular types of bio- 
politics and governance and the masking of pre-existing inequalities; it also leads theorists to a "crisis-thinking" mode of analysis that seeks to offer solutions by abstracting current events from broader socio-political and historical continuities (Dalakoglou, Agelopoulos \& Poulimenakos, 2018, p. 2; see also Cabot, 2016). By drawing on Roitman's work, Davis (2015, p. 1030) argues that "[...] poststructuralist theorists remain unable to articulate this encounter in conceptual terms, and reproduce ruptured epistemologies in the moral critiques by which they distance themselves from the status quo as a historical moment to be escaped or overcome." Within such frameworks, discourses on youth "are often connected with social crises, dramatizing changes in social relationships and in the modalities of power" (Durham, 2004, p. 590), even though "[...] rapid social change need not be experienced as dramatic or unsettling by the young people living through it" (Bucholtz, 2002, p. 530).

\section{Migration, a "Double-Crisis" and Progress}

One significant change since 2010 in the socio-demographic landscape in the Republic of Cyprus is the higher numbers and visibility of Greek migrants. Greek Cypriots often say that "you only now hear kalamaristika" (a colloquial term for Greek spoken in Greece, as opposed to Cypriot Greek), ${ }^{\mathrm{vi}}$ when you walk in the streets of Nicosia or Limassol. Migrant flows from Greece to Cyprus are certainly not a novel phenomenon. However, Greece, as the larger country, and a perceived metropolis and "motherland" by some Greek Cypriots, has been the one historically attracting Cypriots seeking education and employment; rather than vice versa. The recent increased migration from Greece to Cyprus, therefore, demarcates a significant shift from this established pattern that allows to treat such migration as a "new" direction produced largely in response to the economic crisis. ${ }^{\text {vii }}$ 
At the start of the Greek crisis, Cyprus's economy appeared stable. A mainly agricultural society before the war of 1974, after the division, the country had to deal with the severe economic impact of the conflict including unemployment and property loss. However, through projects of modernization and due to a combination of geo-political and economic developments, the Republic of Cyprus experienced rapid reconstruction and redevelopment, which has been popularly described as an "economic miracle." In the decades that followed, the economy grew at an accelerated pace, predominantly due to the expansion of the banking system. Cyprus became a financial hub, functioning mainly on a service-oriented economy (Ioannou, 2014), and an attractive destination for migrants from both non-European and European contexts (Trimikliniotis, 2013). The flow of Greeks to Cyprus post-2010 has to be contextualized within this socio-economic landscape of migration, especially as a large number of Greeks have replaced other migrants_ - predominantly Eastern Europeans — in the hospitality and services industry.

Although geographical mobility is often linked to economic and status mobility (Salazar \& Smart, 2011, p. ii), many migrant jobs involve long working hours, challenging conditions, and relatively low salaries. Yet they are considered better by migrants, compared to jobs in Greece, for which sometimes payment is late or even not guaranteed. Such uncertainty is often described in temporal terms by migrants, who explain that they left Greece in order "not to waste time anymore".

Writing about time, the effects of neoliberal restructuring on young low-middle-class men in North India and their experiences of unemployment, Jeffrey (2010) describes strategies of "timepass." Young men, unable to find jobs in the public sector, which are considered appropriate for their level of education, keep studying and developing their academic profile, while hoping that one day they will secure the right job. Similarly, in Ethiopia, the reluctance of young men to take up jobs that do not match their educational qualifications is linked by 
Mains (2007) to local hierarchies of occupations and shame (yilunnta). "To have yilunnta is to experience an intense shame based on what others think and say about one and one's family" (ibid., p. 660). Whereas in the first context young men have no options of leaving the country due to lack of economic and social capital, in the case of Ethiopia, migration becomes a solution for escaping the stigma associated with particular occupations, as young men can take up jobs abroad away from the vigilant eye of local communities. In the past few decades in Greece, education has been tightly linked to expectations for social and economic mobility, especially for middle and lower-middle class families, but discourses of shame around occupational prospects have been shaped by the language of crisis, quite differently to the case of Ethiopia. Media reports often demonize unemployed young people as "idlers," who choose not to take up jobs that do not match their career aspirations, and instead prefer to be dependent on their families. However, for the participants of this research, it was mostly the uncertainty and lack of security in Greece that motivated their departure rather than a stigma associated with particular jobs, as a number of them had been employed in Greece in similar positions.

Young Greek migrants reproduce temporal frameworks that associate "time-wasting" not only with work precarity in Greece, but also with a protracted condition of being young and unable to mature. This double connotation was articulated by Maria, a 27-year-old with a degree in media studies, who comes from a town in Central Greece, and works as a waitress in a coffee shop in Nicosia owned by a Greek businessman. ${ }^{\text {viii }}$ She normally spends her whole day working in the coffee-shop, sometimes for as long as 15 hours in one shift:

“I wouldn't go back to Greece. To do what? To work in a coffee shop? I do this here for more money. But I don't want to do this job for ever, it's not secure. I want to progress in order to be able to have a family. I don't want to be a mother, whose only job ever has been to work in a coffee shop." 
This idea of progress, of being able to "move on" is echoed in the interviews of a number of research participants and it is mainly connected to improved work and life conditions that will allow for greater independence and transition to a next stage in life. In Maria's narrative, this next stage, the experience of motherhood, reflects broader discourses of gender roles and expectations around parenthood - a considerable milestone for the transition to adulthood. The uncertainty and insecurity — and its impact on delaying settling down, getting married or having children-is a major concern for many migrants, who often reflect on their predicament as a necessary time of perseverance that will allow them to progress. But this sacrifice, as Dolan and Rajak (2018, p. 245) argue in the case of unemployed youth in Nairobi, "is conceived neither in the millenarian sense (self-sacrifice in the current life for redemption in the next), nor as Stakhanovite (sacrificing the self in the service of the nation/greater good)." This is a sacrifice that involves endurance of precarious work and living conditions in the present to be able to advance one's life in the medium-term future.

Evidently, although emigration is employed as a strategy of progressing both professionally and personally, it does not always resolve anxieties about economic security and the transition to "adulthood," especially when migrants find themselves again in working conditions of precarity. These conditions intensified after Cyprus itself experienced a period of economic crisis and austerity. Although the "Cypriot crisis" started manifesting itself in 20102012 mainly due to exposure of Cypriot banks to Greek debt, it intensified in 2013 with a bailout by the EU, ECB and IMF, and a bail-in that involved the haircut savings of Cypriot as well as foreign accounts. Like elsewhere, the debtors and governing bodies introduced "austerity packages," which included privatizations, salary cuts, job losses and weakening of trade unions and further labor vulnerability (Karatsioli, 2014). This context of "crisis-scapes" (Brekke, Dalakoglou, Filippidis \& Vradis, 2014), of intersecting economic and political processes and 
hierarchies, did not only reduce Greek migration to Cyprus for a while, but also pushed existing migrants to leave, or to consider departure, due to being caught in this "double-crisis."

Marilena, who first went to Cyprus in 2009 as a student in international relations and stayed on to work first in the hospitality services and then in an office, described the shifts that took place in the period:

"When I got here they wanted kalamarades as sales people. It was easy to negotiate the salary. 2011 was still a good period and I could do 2-3 jobs at the same time, especially in comparison to Greece. I used to go to Greece and think that it was great that I had these opportunities as a young person which they didn't have in Greece. This makes you mature. After 2013 and the haircut, the company said they wouldn't fire anyone but reduced our salaries. I was planning to go to Brussels but that didn't work out and then I stayed, and they kept me in sales. And although I think the position is a little degrading [for my skills and education], I think I'm good in sales.”

Clearly, economic and political processes and crises not only further entrench and legitimize precarious conditions of labor, but also impact on the ways in which "youth" is discursively constructed and relationally experienced as a condition of "stuckedness" (Hage, 2009). This predicament of stasis, however, does not necessarily rob migrants of their agency to have aspirations and hopes for the future. In spite of discourses in Greece on migrant return, most young migrants do not consider going back, but moving to a new destination. Maria and her partner hope to be able to migrate to the UK, where her sister lives - although new political crises created by Brexit after 2016 raise further anxieties and dilemmas about such decisions. While Marilena did not move to Brussels in 2013, she did eventually migrate to Denmark in 2016. Further geographical mobility, therefore, is imagined and enacted, whenever possible, as a strategy of dealing with the conditions of uncertainty and liminality, and a way of achieving progress and "moving on." 
But not everyone leaves or can leave. Some migrants considered the crisis in Cyprus as less impactful than the crisis in Greece. Yiannis, who works in a shopping mall and feels "too old" at the age of 36 to migrate again somewhere else, reflected on this: "I wasn't affected by the crisis very much. I can't compare it with Greece. It's very clear that there is still a lot of money [circulating] in Cyprus." Such comparative scales of "crisis" founded on individual predicaments and everyday interactions offer frameworks for dealing with precarity, especially when further mobility (both geographical and socio-economic) are not possible. Although unemployment rates and precarity continue to characterize the labor market in Cyprus, similar narratives of economic recovery are also propagated in media reports and political discourses, especially after Cyprus's exit from the imposed Economic Adjustment Program in 2016. For instance, the Cypriot newspaper "Phileleftheros" (10/04/2017) calls Cyprus "the promised land" for Greek migrants and documents a renewed wave of Greek migration post-2016 after a temporary drop in numbers. However, as the next section illustrates, intersecting discourses and regimes of crisis (and recovery), do not only redefine the category of youth and who is included in it, but also shape the concept of the (non-)migrant and experiences in this "promised land".

\section{(Non-)Migrants and shifting boundaries}

In the spring of 2016, I was in a restaurant in Nicosia, eating dinner with four friends who live and work in Cyprus - two Greek Cypriots and two Greeks. After accepting the waiter's offer of fresh fruit at the end of the meal, my Greek friend protested when she realized that this was not complimentary, but had been charged to the bill. "We always charge fruits and desserts," said the waiter, "do you mean that in Greece you get them for free?" Startled by the response, and assuming this was a comment on the economic situation in Greece, the young woman indignantly replied: "Of course we do! Greece is a much superior country!" Shocked by her 
own utterance, she later expressed her frustration with having to deal with such comments: "I don't like being associated with the misery of Greece."

Such frictions are constantly narrated by young migrants in Cyprus and located in social encounters, work places, and interactions with the state. Kalantzis (2015) writes about similar exchanges in the US, in what he calls "everyday international dramas" (ibid., p.1038), the embodied and inter-subjective performances of essentializing discourses on Greece and its crisis. Kalantzis describes how such scenes reproduce cultural binaries between Westerners and North Europeans vis-à-vis South Europeans, that are shaped by processes of nationalization (ibid., p. 1046); people become and act as the embodied representation of their nation and what is an inter-personal experience becomes public and collective. The context of Cyprus, however, demonstrates how such cultural hierarchies and 'crisis' tropes are acted out in the Southern borders of Europe and transform historical processes of "cryptocolonialism" (Herzfeld, 2002) between Greece and Cyprus. As already mentioned, Greece has been constructed by and imagined in nationalist narratives as the cultural and metropolitan center of "Hellenism" and "the motherland" for Cyprus. Such ideological articulations underpinned the inter-ethnic conflict in Cyprus and the division of the island in 1974. Although "ethnic proximity" to Greece has been historically connected to polarized political identities in Cyprus, with the Left putting emphasis on a Cypriot identity and the Right claiming a shared "Greekness" (Papadakis, 2003; Chatzipanagiotidou, 2012), everyday performances and narratives of such cultural formations are more diverse, diffused and fluid. Discourses of crisis, however, have impacted the ways, in which Greece has been imagined even by those who adopt "Hellenocentric" identities, and a new distinction is constructed in public discourses, contrasting the effectiveness of "austerity measures" in Cyprus with the failure of Greece to reform its economy. In line with long-term and dominant Euro-centric orientations in these discourses (Argyrou, 1996), Cypriots are represented as the "good Europeans" and the Greeks as the "unruly children" of Europe. It is 
not only young Greek migrants, but Greece is also deemed metaphorically to be in a protracted state of youth. These ideological and cultural motifs, although certainly not uniformly shared, have played a significant role to new ways of thinking about ethnicity in Cyprus and to a shift of emphasis on "(Greek-) Cypriotness," as opposed to "Greekness."

For a large number of young migrants, such encounters destabilized preconceived ideas and expectations and encouraged reflections on different aspects of (self-)identification. One of the most insightful moments of fieldwork was when I asked a young man about his experience as a migrant in Cyprus. Dimitris, who worked in an office in 2013, looked quite puzzled: "I'm not a migrant, why would you call me a migrant? Cyprus is like a second home for us, Greeks." Beyond academic and politico-legal categorizations, it is evident here that definitions of "migrant" are dependent on particular socio-cultural contexts, hierarchies and ideologies in spite of whether geographical mobility and crossing of borders are involved (Salazar \& Smart, 2011 p.11). Research participants explained that most information that they had about Cyprus before arriving came through schooling in Greece, and curricula that tend to emphasize the tight historical and ethnic connections between the two countries. As the "migrant" is constructed and imagined in Greece and Cyprus as a racialized other within particular hierarchies of ethnicity, an assumed shared ethnic identity, common language and cultural closeness enables a process of self-identification as a "non-migrant." The perceived status of the "non-migrant" allows young migrants to distinguish themselves from other migrant groups and to naturalize their own settlement in Cyprus. It also contributes to overlooking labor conditions and precarity as connected to a shared migrant experience, and often analyzing and enduring their circumstances as an inevitable effect of the crisis. However, it is also in everyday Cypriot discourses that the ambiguity over the "non-migrant" emerges. When I asked for demographic information on Greek migrants, the administrator in the national insurance office answered quite hesitantly: “No, we don't hold any separate information on 
Greek migrants. But they are not really migrants, are they? They are Greek." On the one hand, the presence and visibility of Greek migrants in Cyprus has contributed to shifting discourses about identity through a framework of nationalization; on the other hand, however, their construction as "non-migrants" allows Cypriots to separate this new part of the labor force from other incoming labor, and deal with some of the contradictions that emerge out of the inability to locate the Greek migrants entirely as either part of "the (ethnic) self" or as "the other."

Yet, contradictions and ambivalences of belonging are constantly evoked by migrants, and are articulated as experiences of being a foreigner (xenos [ $\xi \dot{\varepsilon} v o \varsigma])$. Like other Europeans in Cyprus, Greek migrants have to register with the Migration Department within three months of arrival, in order to receive a residence document, commonly known as the "yellow slip." They often highlight that they have to navigate through state bureaucracy in order to secure their national insurance number or health cover, which is often slow and exaggerates the feeling of being in limbo. Even assumed commonalities, such as a shared language, often arise as points of differentiation. Greek migrants, for instance, often claim to struggle with Cypriot Greek as well as with English, which is widely spoken by Cypriots, due to the colonial history and international character of the island. Lack of social and cultural capital are regularly highlighted as the main obstacles in progressing in Cyprus, vis-à-vis Cypriot youth, who can avail of support through local kinship and socio-political networks. As mentioned, precarious working conditions and hardship often intensify such distinctions. A young Greek man, who worked in a large coastal hotel during the unbearably hot Cypriot summer, reproduced such comparison by saying: "We work all day and stay in the hotel in a small room with a fan. There is no air-conditioning, can you imagine? Is there a Cypriot, who would ever let his [sic] kid work in such conditions?" 
Such cultural frameworks of nationalization dominate migrant social and cultural spaces. These include online platforms and groups, social events, or activities, like learning and practising Greek traditional dancing, which operate as opportunities for both sociality and exchanging valuable information on work and everyday practicalities. A popular Facebook group that caters for Greeks in Cyprus features a wide range of posts, from advice on where to find "good coffee," to job advertisements and housing information. Nationality becomes therefore an important element of identification, not only as a socio-cultural framework of belonging but also as a potential resource for support in conditions of mobility, uncertainty and precarity. In a number of interviews, participants explained that the majority of their friends and social acquaintances are other Greeks. Others, however, develop new and multiple forms of belonging, which often involve distancing oneself from other migrants. Manos, who went to Cyprus in 2008, stated that he avoids socializing with other Greeks in order to be able to integrate in Cypriot society and his work environment. He also tries to speak Cypriot rather than kalamaristika in his everyday exchanges, and highlights the diversity of experiences and conditions between "old" and "new" migrants:

"I think I'm one of the privileged Greeks here, even though my salary is not big and I haven't gotten a salary increase in seven years, because the situation doesn't allow it. But the Greeks who came around 2013 and afterwards got jobs for less than 850 Euros [per month]. What can you do with this money? Pay for your car, electricity, rent? And I think there was a status quo created by people who came here and accepted such low salaries. The employers took advantage of Greek migration assuming that 'they don't have money to eat, so they will accept the low salary'.'

Beyond national identification, either as a form of association or an internal process of distancing, young migrants acknowledge that shared experiences have also allowed them to connect across national boundaries with other migrants or Cypriots through an emphasis 
on class identities and hierarchies. Yiannis, who moved to Cyprus from a small town in Northern Greece in 2012 and works in a cafe, describes a move away from the trope of the "non-migrant": "It's not because we are kalamarades [that we have such problems]. Other migrants - and I have a lot of friends from other places - go through the same. And to tell you the truth, those Cypriots, who have lost their jobs, are the same too." Therefore, in spite of a dominant narrative and interpretative framework of nationalization, conditions of mobility, precarity and uncertainty open up spaces for new social and political associations, which can overlap with nationally rooted understandings of belonging. As Glick Schiller and Salazar (2013, p. 186-187) argue, cosmopolitanism, as an openness to difference, is not exclusive to elite mobilities and can also be attributed to non-elite and precarious migrants. Moreover, contexts as the one described here, push us to challenge strict binaries between sameness and difference, and to avoid seeing "rootedness in territory and culture, and cosmopolitan openness as oppositional” (ibid., p.187).

\section{Conclusion}

In the context of ongoing economic crises and restructuring in Southern Europe, youth emigration has been elevated to a significant public and policy concern through connecting discourses of "brain-drain" and "lost generations." Austerity policies and its effects of unemployment, precarity and uncertainty in Greece have resulted in mass emigration, at least for those young people, who possess some economic, social and cultural capital that facilitates mobility. I have argued that although youth is colloquially defined as a biological and temporal stage of the life cycle, it cannot be abstracted from broader socio-political and economic processes, which shape and determine young people's experiences. The case study of Greek migrants to Cyprus illustrates the ways in which conditions of uncertainty and precarity, often interpreted as inherent qualities of youth, are directly related to and aggravated by the politics 
of austerity and migration. Drawing on anthropological approaches, I have also argued that the crisis should not be naturalized as an economic process and context, but has to be analyzed through its historicizing effects that create specific temporalities of discontinuities and ruptures. Within this framework, a crisis-paradigm emerges on thinking about young emigrants in a liminal stage and protracted state of incomplete adulthood. Young migrants employ such interpretative patterns to makes sense of their life and work conditions, and broader dynamics of inequality and precarity. On the other hand, socio-economic processes, such as neoliberal restructuring, austerity and migration do not have totalizing effects but have to be scrutinized in relation to specific localities and produced subjectivities. The complex political and cultural history between Greece and Cyprus provides a particular terrain in which old identities of ethnic relatedness are reproduced, and at the same time challenged and resisted, by migrants. In spite of dominant discourses of "lost generations" that tend to homogenize youth experiences of mobility, young migrants in Southern Europe are active cultural agents (Bucholtz, 2002) with diverse experiences, responses and strategies in navigating a thorny landscape of protracted crisis. 


\section{Endnotes}

\footnotetext{
' Although the economic crisis in Greece started earlier and is considered ongoing, 2010 is the year that Greece signed its first structural adjustment programme and a reference point as the start of the crisis. Almost half a million Greeks have left the country since 2010 (Eurostat, 2018). More than $50 \%$ of these emigrants are classified as young (below 30 years-old) (Labrianidis \& Pratsinakis, 2015), with unemployment levels particularly high for this age group.

ii Greece has also been extensively studied as a country of immigration, including economic migration, forced displacement, "return" migration, and diasporas (see losifides \& King, 1998; Antoniou, 2003; Triantafyllidou, 2010; Dalakoglou, 2010; Cabot, 2014; Christou \& King, 2015; Michail \& Christou, 2016).

iii Greek migration to the north of Cyprus is very limited, although one interview was conducted with a Greek man, who lives in Lefkoşa, in the northern part of the capital. For purposes of brevity, "Cyprus" in this article predominantly refers to the southern part of of the island, which is under the administrative control of the internationally recognized Republic of Cyprus.

iv Although I use the category of migrant to describe the socio-economic and political status of the participants, a number of them do not self-identify as such. This is discussed through the category of the "non-migrant" later in the article.

${ }^{\vee}$ Most statistical and policy data define youth as those under 30 years-old, but the paper makes the point that youth is experienced and conceptualized in this context as an extended period, even by people well in their 30s, who are included here.

vi It derives from the term kalamaras for a male or kalamarou for a female, and is used in everyday speech by Greek Cypriots to refer to people from Greece, some times with pejorative connotations (Argyrou, 1996, p. 51).

vii The number of Greek passport holders in the Republic of Cyprus almost doubled in a decade; rising from 10,781 in 2000 to 20,767 in 2010. And it almost tripled within three years from 2010 to 2013 reaching 27,912 (United Nations Population Division, http://www.un.org/en/development/desa/population/). In 2016, it was estimated that more than 30,000 Greeks resided in Cyprus.

viii As large economic capital has been moved from Greece to Cyprus since 2010, more "Greek" businesses opened in the island and became popular employment hubs for young migrants.
} 


\section{References}

Antoniou, D. A. (2003). Muslim immigrants in Greece: religious organization and local responses. Immigrants \& Minorities, 22(2-3): 155-174.

Argyrou, V. (1996). Tradition and modernity in the Mediterranean: the wedding as symbolic struggle. Cambridge: Cambridge University Press.

Athanasiou, A. (2012). The crisis as "a state of emergency": critiques and resistances. Athens: Savvalas [in Greek].

Boletsi, M. (2017). The Unbearable Lightness of Crisis: (Anti-)utopian and Middle Voice in Sotiris Dmitriou's Close to the Belly. In Tziovas, D. (Ed.). Greece in Crisis: The Cultural Politics of Austerity. London \& New York: IB Tauris.

Brekke, J., Dalakoglou, D., Filippidis, C., \& Vradis, A. (Eds.). (2014). Crisis-scapes: Athens and beyond. Athens: CRISIS-SCAPE.NET

Bucholtz, M. (2002). Youth and cultural practice. Annual review of anthropology, 31(1): 525552.

Cabot, H. (2014). On the doorstep of Europe: asylum and citizenship in Greece. Cabot, H. (2014). On the doorstep of Europe: asylum and citizenship in Greece. Philadelphia, PA: University of Pennsylvania Press.

(2016). Crisis, Hot Spots, and Paper Pushers: A Reflection on Asylum in Greece. Hot Spots, Cultural Anthropology website. https://culanth.org/fieldsights/898-crisis-hotspots-and-paper-pushers-a-reflection-on-asylum-in-greece

Chatzipanagiotidou, E. (2012). Reconsidering the 'Unofficial'History of the Left in Cyprus and the Cypriot Diaspora. In R. Bryant \& Y. Papadakis (Eds.). Cyprus and the Politics of Memory: History, Community and Conflict. London: I.B. Tauris.

Christou, A., \& King, R. (2015). Counter-diaspora: the Greek second generation returns' home'. Cambridge, Massachusetts: Harvard University Press.

Dalakoglou, D. (2010). Migrating-remitting-'building'-dwelling: house-making as 'proxy' presence in postsocialist Albania. Journal of the Royal Anthropological Institute, 16(4): 761777.

(2012). Beyond spontaneity: crisis, violence and collective action in Athens. City, 16(5): 535-545.

\& Agelopoulos, G. (2018) (eds). Critical Times in Greece. London: Routledge.

, G. Agelopoulos \& G. Poulimenakos (2018) De te fabula narratur?

Ethnography of and during the Greek crisis. In Dalakoglou, D. \& Agelopoulos, G. (eds), Critical Times in Greece. London: Routledge.

Davis, E. (2015). "We've toiled without end": Publicity, Crisis, and the Suicide "Epidemic" in Greece. Comparative Studies in Society and History, 57(4): 1007-1036.

Dolan, C., \& D. Rajak (2018). Speculative futures at the bottom of the pyramid. Journal of the Royal Anthropological Institute, 24: 233-255.

Durham, D. (2004). Disappearing youth: Youth as a social shifter in Botswana. American Ethnologist, 31(4): 589-605. 
Erikson, E. H. (1994). Identity: Youth and crisis (No. 7). WW Norton \& Company.

Eurostat (2018) Emigration by age group, sex and citizenship.

http://appsso.eurostat.ec.europa.eu/nui/show.do?dataset=migr emilctz\&lang=en (last accessed (25/04/2018).

Fakiolas, R., \& King, R. (1996). Emigration, return, immigration: a review and evaluation of Greece's postwar experience of international migration. Population, Space and Place, 2(2): 171-190.

Glick Schiller, N., \& Salazar, N. B. (2013). Regimes of mobility across the globe. Journal of ethnic and migration studies, 39(2): 183-200.

Hage, G. (2009). Waiting out the crisis: on stuckedness and governmentality. In G. Hage (Ed.). Waiting. Melbourne: Melbourne University Press.

Herzfeld, M. (2002). The Absence Presence: Discourses of Crypto-Colonialism. The South Atlantic Quarterly, 101(4): 899-926.

(2013). The European crisis and cultural intimacy. Studies in Ethnicity and nationalism, 13(3), 491-497.

Howden, D. \& Y. Baboulias (2015). Who'd be Young and Greek? Searching for a Future after the Greek Crisis. The Guardian, https://www.theguardian.com/global/2015/jul/26/greece-youth-unemployment-debt-crisiseurozone (last accessed on 15 January 2018)

Ioannou, G. (2014). Employment in crisis: Cyprus 2010-2013. The Cyprus Review, 26(1): 107-126.

Iosifides, Th. and King, R. (1998). Socio-spatial dynamics and exclusion of three immigrant groups in the Athens conurbation. South European Society and Politics, 3 (3): 205-229.

Jeffrey, C. (2010). Timepass: Youth, class, and time among unemployed young men in India. American Ethnologist, 37(3): 465-481.

Kalantzis, K. (2015). "Fak Germani": Materialities of Nationhood and Transgression in the Greek Crisis. Comparative Studies in Society and History, 57(4): 1037-1069.

Karatsioli, B. (2014). Cyprus in Europe:(In)-dependence and In-debtedness. The Cyprus Review, 26(1): 15-32.

Katz, C. (2004). Growing up global: Economic restructuring and children's everyday lives. Minneapolis: University of Minnesota Press.

Knight, D. M. (2012). Cultural proximity: crisis, time and social memory in central Greece. History and Anthropology, 23(3): 349-374.

Labrianidis, L., \& Pratsinakis, M. (2015). Outward migration from Greece during the crisis, Final Report. Project funded by the National Bank of Greece through the London School of Economic's Hellenic Observatory.

Mains, D. (2007). Neoliberal times: Progress, boredom, and shame among young men in urban Ethiopia. American Ethnologist, 34(4): 659-673. 
Michail, D., \& Christou, A. (2016). East European Migrant Women in Greece.

Intergenerational Cultural Knowledge Transfer and Adaptation in a Context of Crisis.

Südosteuropa, 64(1): 58-78.

Papadakis, Y. (2003). Nation, narrative and commemoration: Political ritual in divided Cyprus. History and Anthropology, 14(3): 253-270.

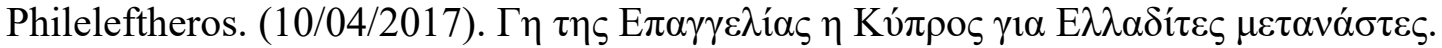
http:/www.philenews.com/oikonomia/kypros/article/385846/g-tis-epangelias-i-kypros-gaelladites-metanastes (last accessed on 10 December 2017).

Rohrer, I. (2014). Anthropology and Youth. In Cohesion and Dissolution (pp. 37-45). Springer Fachmedien Wiesbaden.

Salazar, N. B., \& Smart, A. (2011). Anthropological takes on (im)mobility. Identities, 18(6): i-ix.

Smith, H. (2015). Young, gifted and Greek: Generation $\mathrm{G}$ - the world's biggest brain drain. The Guardian, https://www.theguardian.com/world/2015/jan/19/young-talented-greekgeneration-g-worlds-biggest-brain-drain (last accessed on 15 January 2018)

Triantafyllidou, A. (2010). Twenty years of Greek immigration policy. Immigration in Greece of the 21st century. Athens: Kritiki (in Greek).

Trimikliniotis, N. (2013). Migration and Freedom of Movement of Workers: EU Law, Crisis and the Cypriot States of Exception. Laws, 2(4): 440-468. 